\title{
The length of coastlines in Ptolemy's Geography and in ancient periploi
}

\author{
Dmitry A. Shcheglov \\ S.I. Vavilov Institute for the History of Science and Technology, St. Petersburg, Russian Federation \\ Correspondence: Dmitry A. Shcheglov (shcheglov@yandex.ru)
}

Received: 2 July 2017 - Revised: 22 November 2017 - Accepted: 2 December 2017 - Published: 1 February 2018

\begin{abstract}
The lengths of the coastlines in Ptolemy's Geography are compared with the corresponding values transmitted by other ancient sources, presumably based on some lost periploi (literally "voyages around or circumnavigations", a genre of ancient geographical literature describing coastal itineraries). The comparison reveals a remarkable agreement between them, suggesting that Ptolemy relied much more heavily on these or similar periploi than it used to be thought. Additionally, a possible impact of Ptolemy's erroneous estimate of the circumference of the Earth is investigated. It is argued that this error resulted in two interrelated distortions of the coastal outlines in Ptolemy's Geography. First, the north-south stretches of the coast that were tied to particular latitudes are shown compressed relative to the distances recorded in other sources in roughly the same proportion to which Ptolemy's circumference of the Earth is underestimated relative to the true value. Second, in several cases this compression is compensated by a proportional stretching of the adjacent east-west coastal segments. In particular, these findings suggest a simple explanation for the strange shape of the Caspian Sea in Ptolemy's Geography.
\end{abstract}

\section{Introduction}

Classics (or studies of Greco-Roman antiquity), which is the field that the history of ancient geography and cartography belongs to, is a very old discipline. So, as time goes by, the chance to find something really new in this field, or to do something that nobody has ever done before, tends to zero. Ptolemy's Geography (ca. AD 150) is a happy exception to this tendency. Although the Geography is one of the most famous and often-studied works in the history of cartography, its origins still remain an enigma. However, in the last decade, after the publication of its new edition by Stückelberger and Graßhoff (2006), Ptolemy's Geography has seen an upsurge of scholarly interest. Numerous researchers have developed a wide array of different methodological approaches to studying its nature and genesis (e.g. Isaksen, 2011, 2013; Marx, 2011, 2016; Heß, 2016; Shcheglov, 2017; Graßhoff et al., 2017; Arnaud, 2017; Defaux, 2017). One of the main approaches is a comparison with other ancient sources. Surprisingly, until this day nobody has ever tried to compare Ptolemy's Geography with the ample data on coastline length provided mostly by Agath- emerus in his Geographical Sketch (the 1st century AD) and by Pliny the Elder in the geographical books of his Natural History (AD 77-79). The objective of the present study is to fill this gap. My contention is that this comparison can shed some new light on Ptolemy's modus operandi and the genesis of his Geography.

\section{Periploi among the sources of Ptolemy's Geography}

Ptolemy's Geographical Guide, or simply the Geography, was essentially a description of the world map in terms of spherical coordinates (latitude and longitude in degrees) assigned to each of the 6300 listed localities. ${ }^{1}$ However, it is clear that only some of these coordinates could have been based on astronomical observations (e.g. the latitudes of the

\footnotetext{
${ }^{1}$ Consequently, the term "Ptolemy's Geography" may be used synonymously with "Ptolemy's map" when referring to a map reconstructed from the coordinates recorded in the text. These coordinates are now available in an electronic database attached to the edition of the Geography by Stïckelberger and Graßhoff (2006).
} 
major cities: Alexandria, Rhodes, Athens, Rome, Massalia, etc.). Ptolemy's predecessors and possible sources described geographic space mostly in terms of distances measured in customary units (Greek stades, Roman miles, etc.). ${ }^{2}$ It is reasonable to suppose, therefore, that, with few exceptions, Ptolemy's coordinates were derived from distances converted to angular units (Cuntz, 1923, p. 110; Knapp, 1996, p. 3035; Graßhoff et al., 2017; Arnaud, 2017, pp. 3, 14-20). This makes comparison of Ptolemy's Geography with other surviving sources a promising way to investigate its organization and genesis. Interestingly, there are a lot of studies comparing Ptolemy's distance data with the Roman itineraries (or descriptions of the land routes), ${ }^{3}$ but only a few attempts to compare them with the Greek periploi. ${ }^{4}$

Periploi (sing. periplus) is a genre of ancient geographical literature describing coastlines in the form of a linear succession of stopping points and intervening distances. Periploi are considered to be "the standard basis of ancient descriptive geography" (Purcell, 2012, p. 1107). ${ }^{5}$ Many ancient geographers - Artemidorus, Strabo, Pomponius Mela, Pliny the Elder (in Books III-VI of his Natural History), Dionysius Periegetes, etc. - presented their works in the form of periploi, even though they actually did not confine their narratives to the coasts. Ptolemy himself emphasizes (Geogr. 1.18.6) that it is much easier to indicate the positions of the coastal cities than of the inland ones. It is reasonable to suppose, therefore, that in many respects it was periploi that provided the foundation for his map of the world.

Only a few periploi survived from antiquity and only four of them provide detailed information on distances: three Periploi of the Pontus Euxinus (Black Sea) and the Stadiasmus of the Great Sea (Mediterranean). ${ }^{6}$ These sources, how-

\footnotetext{
${ }^{2}$ The length of the stade is a vexed issue. The majority of ancient sources use the ratio of 1 Roman mile (for which the standard notation is m.p. or mille passuum) to 8 Greek stades. This ratio is used throughout the present paper. Since the Roman mile measures about $1480 \mathrm{~m}, 1$ stade is equal to ca. $185 \mathrm{~m}$. For a detailed discussion with references to relevant literature, see Shcheglov (2016b, p. 694-701).

${ }^{3}$ Cuntz (1923), Spaul (1958, p. 5-7), Seabra Lopes (19951997), Knapp (1996), Meuret (1998), Gómez Fraile (2005), Urueña Alonso (2014a, b).

${ }^{4}$ Mittenhuber (2012) compares Ptolemy's Hispania (i.e. the Iberian Peninsula) with the distance data from the so-called Artemidorus papyrus, while Marx (2016) compares Ptolemy's Atlantic coast of Africa with the distance data from Pliny's Natural History.

${ }^{5}$ On periploi as one of the basic forms of geographical description in antiquity, see Janni (1984).

${ }^{6}$ Two Periploi of the Pontus Euxinus (Black Sea) composed by Menippus of Pergamon (the end of the 1st century BC) and Flavius Arrian (the beginning of 2nd century AD) served as the sources for the third and fuller Periplus known under the name of Pseudo-Arrian (3rd century AD). The standard edition of these three periploi is Diller (1952, p. 103-146). The anonymous Stadiasmus of the Great Sea (1st century AD; for this dating, see Uggeri, 1996) describes the coasts of Africa from Alexandria to Carthage and of Asia
}

ever, deserve a more thorough examination elsewhere. Fortunately, thanks mainly to the Geographical Sketch by a certain Agathemerus (Diller, 1975) and to Books III-VI of Pliny's Natural History (Jan and Mayhoff, 1892), as well as to some other sources, we have a set of values for the total coastline lengths of the major regions as recorded by the most famous ancient geographers: Eratosthenes (the 3rd quarter of the 3rd century BC), ${ }^{7}$ Artemidorus of Ephesus (ca. 104100 BC), ${ }^{8}$ Marcus Vipsanius Agrippa (ca. 12 BC), ${ }^{9}$ Isidore of Charax (around the turn of the 1st centuries BC and AD), and some others. These values evidently derive from some lost periploi.

This data set covers the largest part of the then-known world (Figs. 2 and 3). First of all, Artemidorus, Isidore, and Agrippa give the lengths of the coastlines of the "Inner" Sea (Mediterranean, Black, and Azov seas) as a whole and as divided between the three continents: Europe from the Pillars of Hercules (or Calpe, i.e. Gibraltar) to the mouth of the Tanais (Don), Asia from the Tanais to the Canobic (westernmost) mouth of the Nile, and Libya (Africa) from this mouth to Tingis (Tangier). The same geographers and some other authors give the perimeters of the major peninsulas (the Pyrenean, the Italian, the Arabian), seas or gulfs (the Persian Gulf and the so-called "second" and "third" gulfs of Europe i.e. roughly speaking, the Adriatic, Ionic, and Aegean seas and the Red, Black, Azov, and Caspian seas), and the largest islands. The fact that different authors reproduce almost the same or similar set of values suggests that these data were regarded as a special category to be included in a geographical treatise. For the sake of completeness, we will add to this set several values of the total coastline lengths reported by the surviving "detailed" periploi: Pseudo-Arrian's Periplus and the Stadiasmus, as well as by Strabo's Geography (ca. AD 23), our main source on its subject matter (Radt, 20032011).

from Aradus to Miletus including the adjacent islands of Cyprus and Crete. The most reliable edition is still Müller (1855, p. 427-563); a new edition is being prepared by Pascal Arnaud. These periploi may be called "detailed" in the sense that, unlike other surviving periploi, they divide the route into hundreds of course legs with the median length of ca. 90 stades or $16-17 \mathrm{~km}$. On the ancient methods of maritime distance estimation, see Arnaud (1993).

${ }^{7}$ Eratosthenes was probably the most famous ancient geographer before Ptolemy. His geographical treatise has survived only in fragments; for the editions, see Berger (1880) and Roller (2010).

${ }^{8}$ Schiano (2010).

${ }^{9}$ Marcus Vipsanius Agrippa (63-12 BC) was the right arm of the emperor Augustus. According to Pliny's testimony (Natural History 3.17 ), he left behind an unfinished geographical work which, as most scholars believe, served as the basis for a world map displayed in the Porticus Vipsania in the centre of Rome (before AD 14). The map was accompanied by explanatory notes with an account of dimensions and boundaries of 24 regions of the world. These notes have come down to us only in fragments; the standard edition is Klotz (1931). 
The objective of this paper is to compare this data set with the lengths of the corresponding coastlines in Ptolemy's Geography. But before attempting the comparison there are several methodological issues we need to discuss.

\section{Method of comparison}

How can we measure the lengths of the coastlines in Ptolemy's work? My contention is that the simplest and most natural way would be to take Ptolemy's Geography as what it essentially is, namely as a catalogue of spherical coordinates. The distance between two points specified by these coordinates is an arc of the great circle that can be calculated using the rules of spherical trigonometry. ${ }^{10}$ Accordingly, I propose to calculate the length of the coastlines in Ptolemy's Geography as the sum of individual arcs joining coastal points multiplied by the length of a degree of the great circle which he defines as 500 stades (Geogr. 1.7.1, 11.2).

It is important to emphasize that actually next to nothing is known about how Ptolemy worked with his sources and how he converted their distance data into coordinates (Graßhoff et al., 2017, p. 2, 6-7; Defaux, 2017, p. 12, 255). It is hard to imagine that he would have calculated the coordinates for each of the 6000 points listed in his Geography. It would be more reasonable to assume that calculations may have been performed only for the most important points, whereas all others were localized by means of simpler methods, for example, Pythagoras' theorem and/or a simple ruler; cf. similarly Spaul (1958, p. 5-7) and Graßhoff et al. (2017, p. 1, 16, 25).

Ptolemy's coordinates are specified with precision up to $5^{\prime}$. This, however, must not mislead us about the accuracy of his data. The precision of Ptolemy's coordinates correlates clearly with the density of the points on his map: its "rarest" parts at the periphery (such as Asian Scythia or Inner Libya) have the highest percentage of coordinates in whole degrees, but as we approach the Mediterranean, the fractions of a degree become increasingly more frequent and smaller. In other words, Ptolemy's coordinates can be precise not so much because his sources were accurate, but rather in order to fit many points in a confined space. Statistical analysis of the frequency of different fractions of a degree used in Ptolemy's coordinates shows that he tended to round all values to the largest possible fractions. ${ }^{11}$ It means that, fig-

\footnotetext{
${ }^{10}$ The distance between points $\mathrm{A}$ and $\mathrm{B}$ situated on a sphere can be calculated by the formula $\cos S_{\mathrm{AB}}=\cos \Delta \lambda_{\mathrm{AB}} \cdot \sin \left(90^{\circ}-\varphi_{\mathrm{A}}\right)$. $\sin \left(90^{\circ}-\varphi_{\mathrm{B}}\right)+\cos \left(90^{\circ}-\varphi_{\mathrm{A}}\right) \cdot \cos \left(90^{\circ}-\varphi_{\mathrm{B}}\right)$, where $S_{\mathrm{AB}}$ is the distance between points $\mathrm{A}$ and $\mathrm{B}$ expressed in degrees of the great circle, $\Delta \lambda_{\mathrm{AB}}$ is the longitudinal interval between them, $\varphi_{\mathrm{A}}$ and $\varphi_{\mathrm{B}}$ are their latitudes. Certainly, Ptolemy did not have trigonometric formulas in their modern form, but the theorems of Menelaus that he used to solve similar problems in the Almagest were an ancient equivalent of them (Neugebauer, 1975, p. 21-30).

${ }^{11}$ The frequency of different fractions of a degree in Ptolemy's catalogue of coordinates conforms to a normal distribution: the co-
}

uratively speaking, Ptolemy's map had "low resolution": it could reproduce general outlines of large objects, but was quite inaccurate in details. For this reason, when comparing Ptolemy's data with the distances reported by other sources, it makes sense to consider only those applying to relatively long intervals. It also needs to be born in mind that, owing to the peculiarities of the map, close matches can hardly be expected from this comparison.

The text of Ptolemy's Geography has been handed down to us in two recensions: $\Xi$ and $\Omega$ (Fig. 1). ${ }^{12}$ Both of them descend from antiquity, but none of the extant manuscripts dates earlier than the late 13 th century. The $\Xi$ recension is considered to be earlier and more authentic, but it is represented by the sole manuscript Vaticanus Graecus 191 (ca. AD 1295) which omits all coordinates for the eastern half of the map (i.e. for the whole Asia, except for Asia Minor, Armenia, and Asiatic Sarmatia) and contains quite a few scribal errors. The $\Omega$ recension is apparently secondary to $\Xi$, but it includes the majority of the manuscripts. ${ }^{13}$ In view of these circumstances, when comparing Ptolemy's data with the distances recorded in other sources, both recensions should be taken into account, but $\Xi$ should be regarded as more reliable.

\section{Comparison of the coastline lengths in Ptolemy's Geography and in other sources}

Let us turn to the sources. All data needed for comparison are given in Table 1, which constitutes the core of this paper, and are illustrated by Figs. 2-7. Table 1 compares the coastline lengths derived from Ptolemy's coordinates (in $\Xi$ and $\Omega$ ) with the corresponding distances given in the other sources, presumably based on periploi. ${ }^{14}$ Also, the table shows how much Ptolemy's values deviate from those of the

ordinates in integer degrees, without fractions, are the most frequent, those with $1 / 2^{\circ}$ are less frequent, those with $1 / 3$ or $2 / 3^{\circ}$ are still less, those with $1 / 4$ or $3 / 4^{\circ}$ and $1 / 6$ or $5 / 6^{\circ}$ are still less again, and those with $1 / 12,5 / 12,7 / 12$ or $11 / 12^{\circ}$ are the rarest; see Wurm (1931, p. 25-27), Marx (2011, p. 30-36), Isaksen (2011, p. 262-264, 2013, p. 48-50).

${ }^{12}$ For a detailed discussion of the manuscript (MSS) tradition, see e.g. Schnabel (1938), Stückelberger and Graßhoff (2006, p. 3034), Burri (2013, p. 63-93), for a good synopsis, see Defaux (2017, p. 67-81).

${ }^{13}$ See e.g. Cuntz (1923, p. 15-16), Schnabel (1938, p. 44, 55-57), Burri (2013, p. 540-542). Polaschek (1965, cols. 717, 742-744) and Berggren, Jones (2000), p. 43-45 argued that the $\Omega$ recension represents a post-Ptolemaic Byzantine revision, whereas codex Vaticanus Graecus 191 is the only piece of Ptolemy's genuine text. However, I see no sufficient grounds for such a radical position; see similarly Defaux (2017, p. 80-81).

${ }^{14}$ All Ptolemy's coordinates are taken from the electronic database attached to the newest edition of the Geography (Stückelberger and Graßhoff, 2006) and are appended to the present paper as Excel files in the Supplement. 


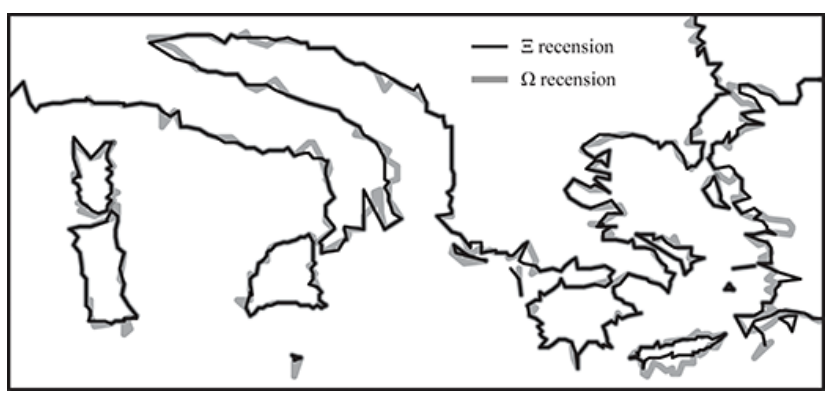

Figure 1. The outlines of the Mediterranean Sea according to the $\Xi$ and $\Omega$ recensions of Ptolemy's Geography (Italy, the Balkans, and the Aegean Sea are taken as an example). This and all the other maps in the paper are drawn using the projection attributed by Ptolemy to Marinus of Tyre (Geogr. 1.20.3-5), whom he introduces as his immediate predecessor and the primary source of information (Geogr. 1.6.1). In modern terms, it is an equidistant cylindrical projection, in which the ratio between equal latitudinal and longitudinal intervals is represented as $5: 4$.

other sources, and how much $\Omega$ deviates from $\Xi$, both in terms of stades and in terms of percentage.

What conclusions can be drawn from this comparison? First of all, our sample clearly falls into two parts: shorter and longer distances. Islands and other small features (such as Peloponnesus or no. 18 in Table 1, the Great Syrtis or nos. 7 and 17, etc.) or relatively short coastal stretches exhibit little similarity between Ptolemy's data and the periploi data (the only exceptions are Sicily nos. 15 and 16, Crete no. 8, and Illyria nos. 1 and 9; Figs. 3 and 7) This result accords with the fact that Ptolemy's map had a low resolution and was in principle incapable of representing small features accurately.

However, for longer distances, with a threshold being approximately at 10000 stades, the pattern changes radically. It is instructive to remember that, with only a few exceptions, these coastlines are very long and have very complex geometry. In these circumstances, one can hardly expect any similarity between Ptolemy's figures and the periploi figures at all. Nevertheless, the correspondences between them are so numerous and so close (Fig. 4) and their geographical coverage is so wide (Figs. 2 and 3 ) that this can reasonably be regarded as something more than just a series of coincidences.

Figure 4 shows that in most cases the differences between Ptolemy's data and the periploi-based sources fall between +4 and $-1 \% .{ }^{15}$ How can we interpret these values? Is it a lot or not? Previous researchers who compared Ptolemy's data with the distances recorded in other sources regarded

${ }^{15}$ Of course, it is possible to find many contradictions between Ptolemy's data and distances reported by other sources, but there is no reason to expect them to match always and everywhere. For example, Pliny gives evidently incredible and fictional values for the coastlines of Germania (4.98 = Agrippa F 21; see Riese, 1878, p. 5) and Gaul (4.105 = Agrippa F 23 Riese = F 40 Klotz): 20000 and 14000 stades, respectively. the 5-10\% difference between them as small enough to suggest a common origin (Cuntz, 1923, p. 120-122, 144-145; Urueña Alonso, 2014a, p. 164, 169-170; Marx, 2016, p. 3334). But for a more robust assessment, it would be informative to compare the differences between Ptolemy and the other sources with the differences between the two recensions of Ptolemy's own work (see Table 1 and Figs. 5, 6). A convenient benchmark for this comparison is provided by the measurements of the "Inner" Sea (Mediterranean and Black seas without the Azov Sea). ${ }^{16}$ In the $\Xi$ recension, its perimeter measures 133792 stades, which is $2.8 \%$ longer than according to Artemidorus (130 120, no. 50 in Table 1), but in $\Omega$ it is $1.8 \%$ longer (136 231) than in $\Xi$. Remarkably, in a number of cases the differences between $\Xi$ and $\Omega$ are appreciably larger than those between $\Xi$ and the other sources: Europe from Calpe to the Tanais (no. 48 in Table 1), Hispania (33), Italy (29), the "second gulf" of Europe (26), and the Red Sea (28). If we still believe that $\Xi$ and $\Omega$ are, despite all the disagreements between them, two versions of the same work by the same author, the similarity between Ptolemy's $\Xi$ values and those reported by the other sources cannot be dismissed as a coincidence.

It makes sense to take a closer look at the outliers. First of all, however obvious it may seem, it is worth noting that, when ancient sources give different estimates for the same coastline, Ptolemy's data cannot agree with all of them. For instance, when Ptolemy's data match one of the two known values for the perimeter of Arabia (no. 45: 38120 stades), they must naturally disagree with the other (no. 44: 32 000). The same is true for the Great Syrtis (nos. 7 and 17), the Maeotis $(22,25)$, Hispania $(33,38)$, the Pontus Euxinus (3537, 39), Africa (40-43), and the Mediterranean without the Pontus (49, 50). Taking this into account, only two outliers stand out: the Red Sea coast of Arabia (no. 27) and the Mediterranean coast of Africa (nos. 40-43). The estimated 14000 stades for the Arabian coast, repeated by Eratosthenes, Artemidorus, and Agrippa, goes back as far as to Alexander's commander Anaxikrates and was regarded as "too much" ('̇ंì $\pi \lambda \dot{\varepsilon}$ ov) already by Strabo (16.4.4 C768). But it seems that the best way to explain a drastic reduction of this coast by $22 \%$ in Ptolemy's Geography would be to link it to his adoption of an erroneous value for the circumference of the Earth (see below Sect. 5). The case of Africa seems to be more complicated: Ptolemy's distance is $5 \%$ shorter than the Stadiasmus' value for the coast between Alexandria and Utica (no. 30), but it is $5.66 \%$ longer than the largest value recorded by Pliny (no. 43) for the coast between Canobus and Tingis. Yet, it is remarkable that Pliny calls this value "the average of all the various accounts" (6.208: ut media ex

\footnotetext{
${ }^{16}$ It is important to emphasize that Artemidorus, followed by the majority of other ancient authors, estimated the circumference of the Maeotis (Azov Sea) at 9000 stades, whereas Ptolemy may have adopted an alternative estimate of 11248 stades attested by Pliny 4.78 .
} 


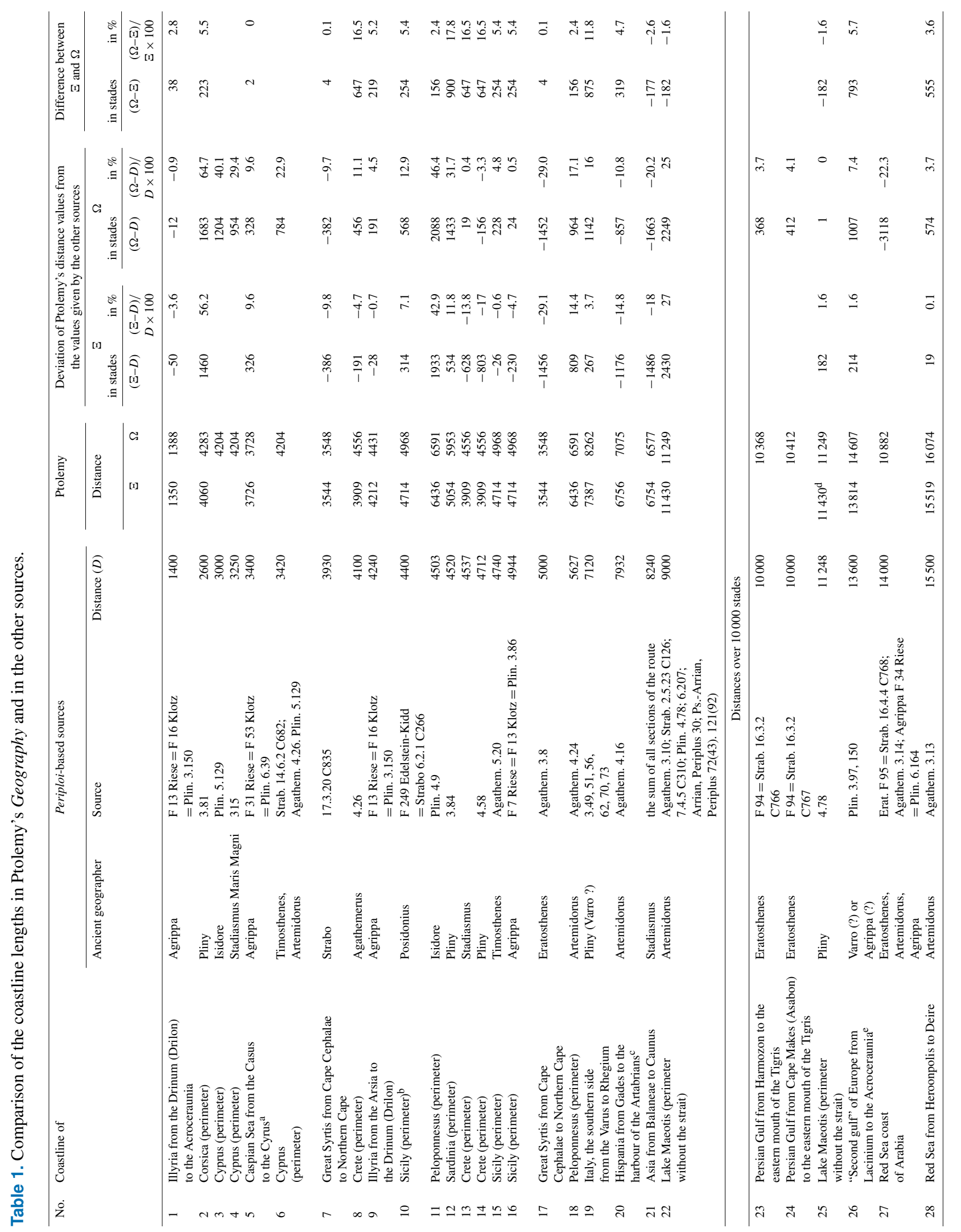




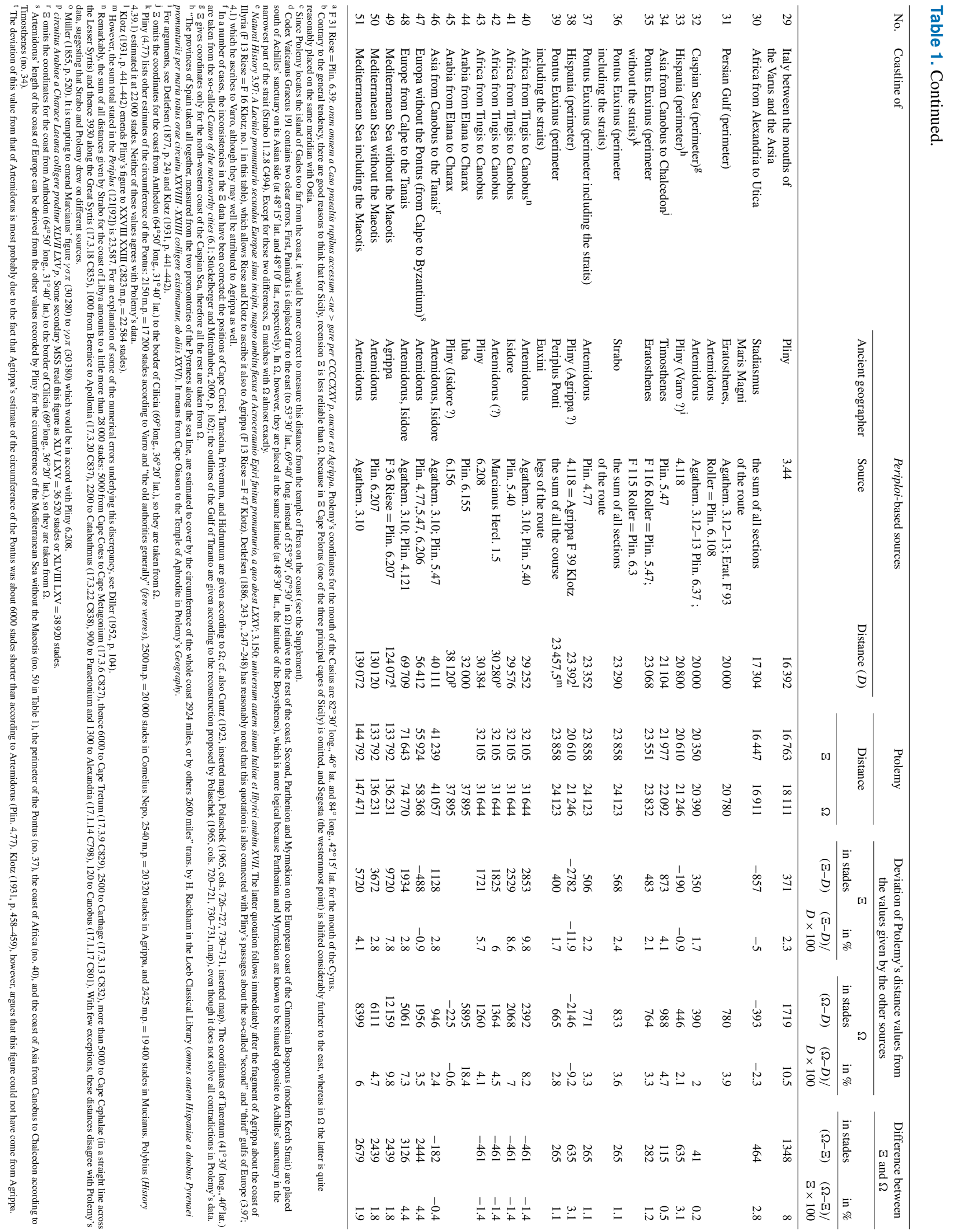




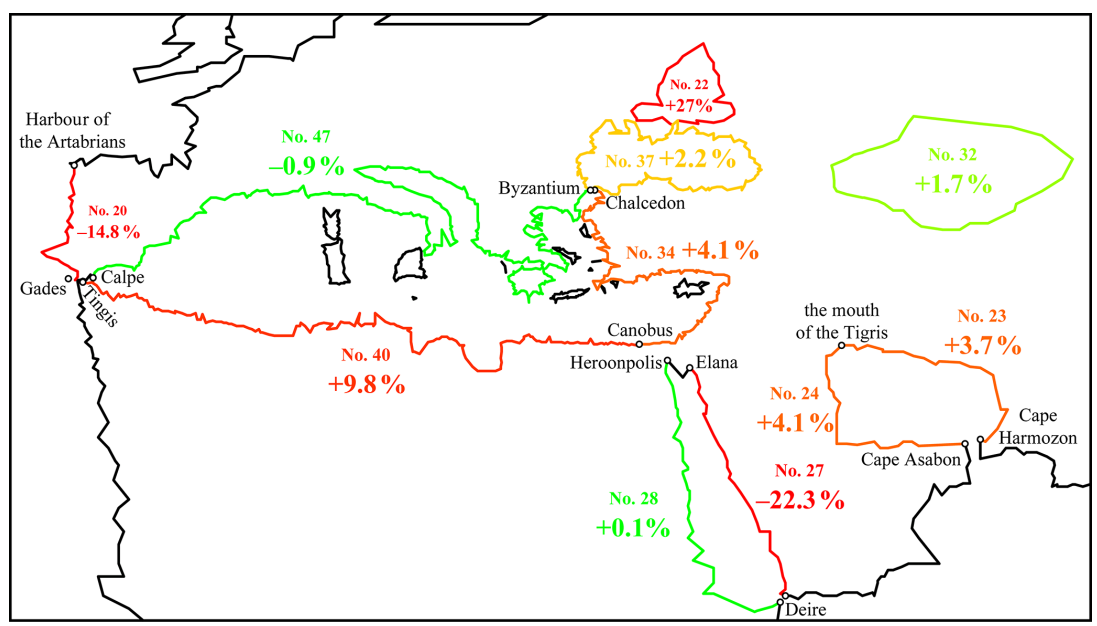

Figure 2. Differences between the coastline lengths as derived from Ptolemy's coordinates and as given by Artemidorus (including those that he has inherited from Timosthenes and Eratosthenes: nos. 20, 22-24, 27-28, 32, 40, 46-47 in Table 1). The percentages refer to the deviation of Ptolemy's values from those of Artemidorus. The outlines are drawn according to the $\Xi$ recension supplemented with coordinates from $\Omega$ for the areas of Asia that are missing in $\Xi$.

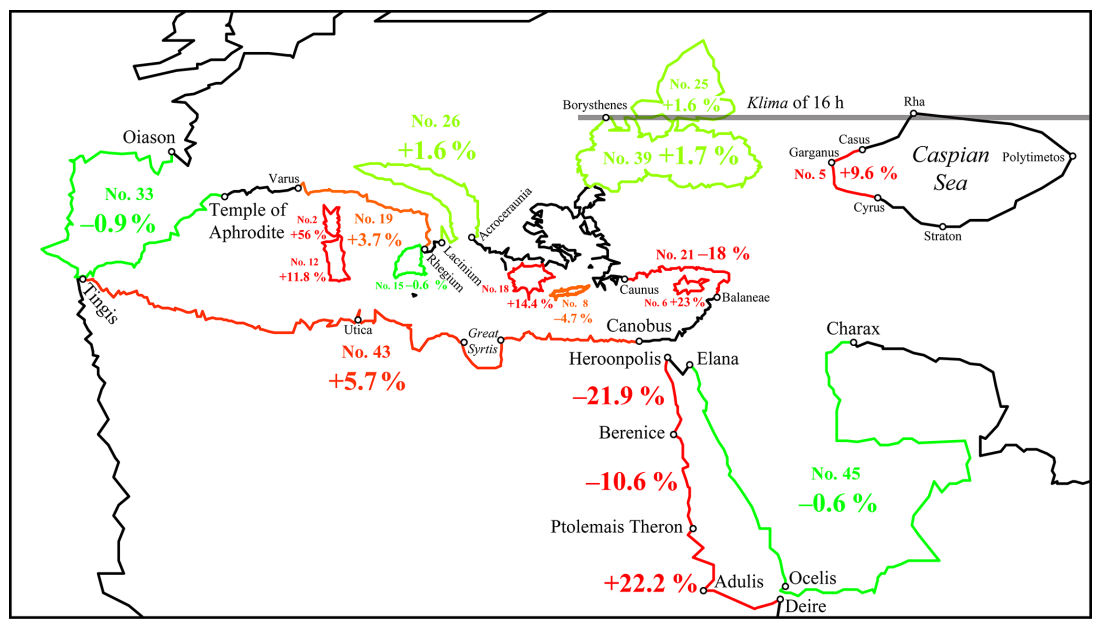

Figure 3. Differences between the coastline lengths as derived from Ptolemy's coordinates and as given by other periploi-based sources (nos. 2, 5-6, 8, 12, 16-19, 21, 25, 28, 33, 39, 43-44 in Table 1). The percentages refer to the deviation of Ptolemy's values from those of other sources. The outlines are drawn according to the $\Xi$ recension supplemented with coordinates from $\Omega$ for the areas of Asia that are missing in $\Xi$.

omni varietate prodentium sumatur computatio), which implies that he knew even larger estimates.

Remarkably, Table 1 shows that the distances in $\Xi$ are usually shorter than in $\Omega$, but longer than in the other sources. This ratio can easily be explained by the so-called coastline paradox: the well-known fact that a coastline length varies depending on the level of detail of its geometry. The periploi described, of course, the coastal routes. However, these routes did not have to replicate all the minor, but numerous curves and bends of the coast. It is unsurprising, therefore, that the coastline in Ptolemy's Geography, when measured with all its curves, proves to be a little longer than the distances recorded in periploi, and $\Omega$, as the second recen- sion, has usually a more detailed and, therefore, even longer coastline than $\Xi$ (Fig. 1).

\section{The influence of Ptolemy's erroneous estimate of the circumference of the Earth}

Distance data derived from periploi were bound to come into conflict with other Ptolemy sources, and particularly with his latitude data. In this case, contradictions must have been especially prominent because Ptolemy adopted an erroneous value for the Earth's circumference, namely 180000 stades, which was about $17 \%$ less than the actual value, if he used the stade of $185 \mathrm{~m}$ length (Shcheglov, 2016b). Owing to this 


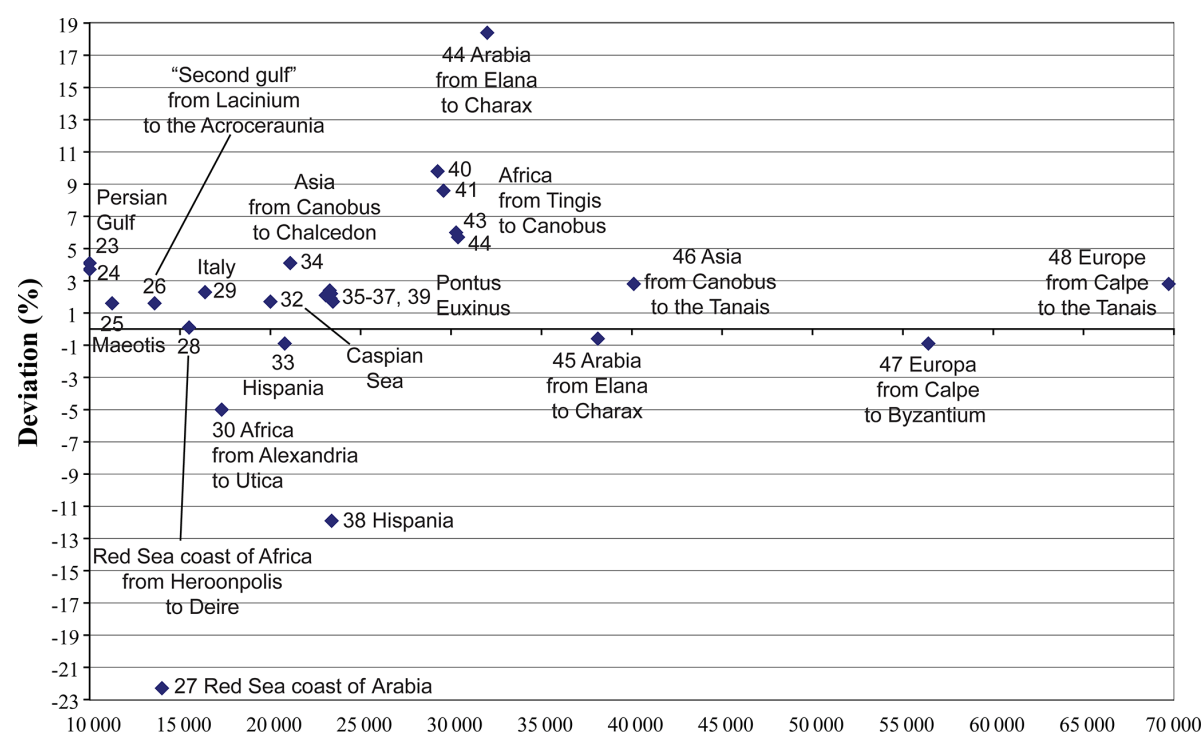

Length of the coastline (stades)

Figure 4. Deviation of Ptolemy's coastline length values from those given in the periploi-based sources for the distances over 10000 stades (as expressed in the percentage terms). Ptolemy's data are mostly taken from $\Xi$ and in a few cases from $\Omega$ (nos. 23-24, 27, 32, 44-45). Nos. 31, 49-51 are omitted since they are the sums of the other values.

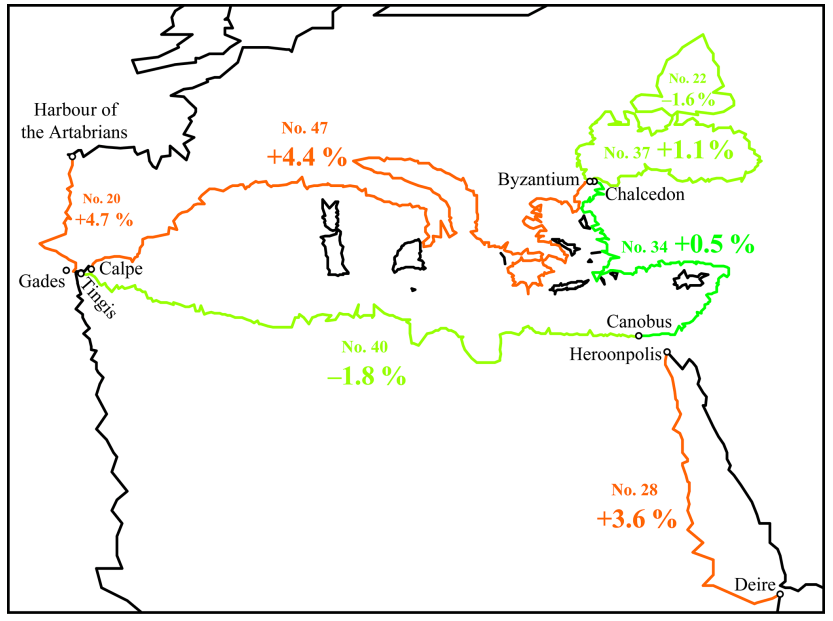

Figure 5. Differences between the coastline lengths in $\Xi$ and in $\Omega$ as expressed in terms of percentage of the $\Xi$ values (for the same coastal stretches as shown on Fig. 2).

error, all north-south distances which were tied to particular latitudes must also have been reduced by approximately the same amount. This effect may be illustrated by the example of the Red Sea coast of the Arabian Peninsula (no. 27 in Table 1). In Ptolemy's Geography, this coast is squeezed between the latitude of its northern extremity (Elana, 29 $15^{\prime}$ ) and that of Ocelis $\left(12^{\circ}\right)$ near the Strait of Deire (Bab-elMandeb), the latter being based on astronomical observations (Ptol. Geogr. 1.7.4). It is unsurprising, therefore, that this coast exhibits a $22 \%$ reduction in length.
However, I would like to draw attention to another possible and arguably more unusual side-effect of Ptolemy's underestimated circumference of the Earth. This effect is observed when a coastline in Ptolemy's Geography falls into two distinct parts: one oriented north-south, the other east-west. In a number of such cases the same pattern is seen: while the north-south part is shorter than the recorded periploi distance, which is understandable, the east-west part is proportionally longer, which requires explanation. It is reasonable to suppose that such a stretching of the east-west parts was intended to compensate for the shortening of the north-south part in order to maintain the total coastline length unchanged. If this explanation is valid, it can give us an important key to understanding Ptolemy's modus operandi.

The effect of proportional shortening/stretching of the neighbouring segments of the coast can be illustrated most clearly by three examples: Italy, the Caspian Sea, and the Red Sea. In the case of Italy, the southern part of the peninsula is squeezed between the latitudes of the Strait of Messina (at Rhegium) and Naples, whereas the part between Naples and Ostia is proportionally stretched from east to west (Fig. 7). The Caspian Sea is probably compressed from north to south together with the circumference of the Earth, but proportionally stretched from east to west (Figs. 2 and 3). In the case of the Red Sea, the largest part of its African coast is oriented from north to south and squeezed between the latitudes of its northern extremity and of Ptolemais Theron in the south, whereas its southern part, turning eastward to the Bab-elMandeb Strait, is proportionally stretched (Fig. 3). Below I consider these instances in detail. 


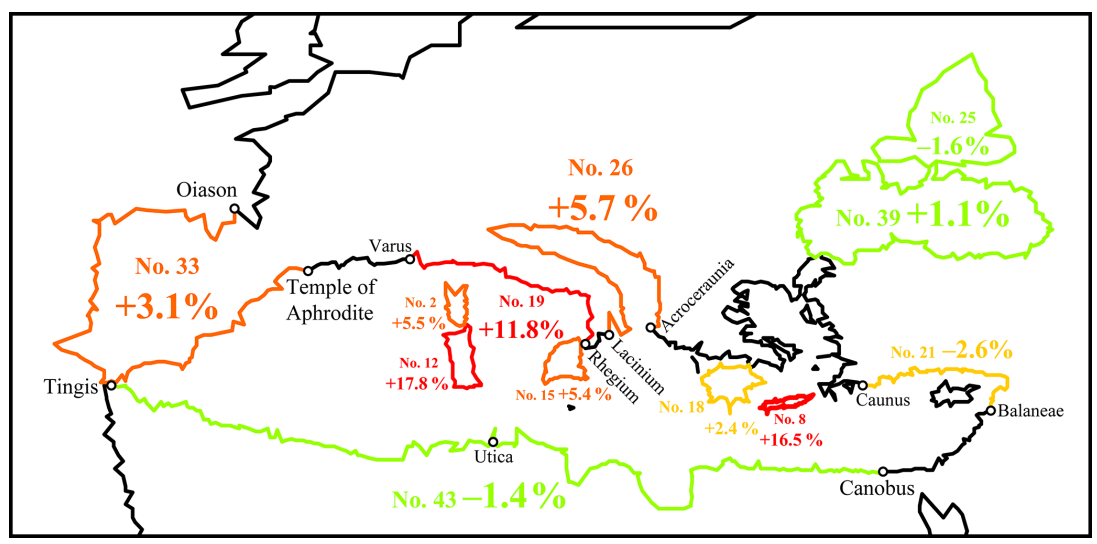

Figure 6. Differences between the coastline lengths in $\Xi$ and in $\Omega$ as expressed in terms of percentage of the $\Xi$ values (for the same coastal stretches as shown on Fig. 3).

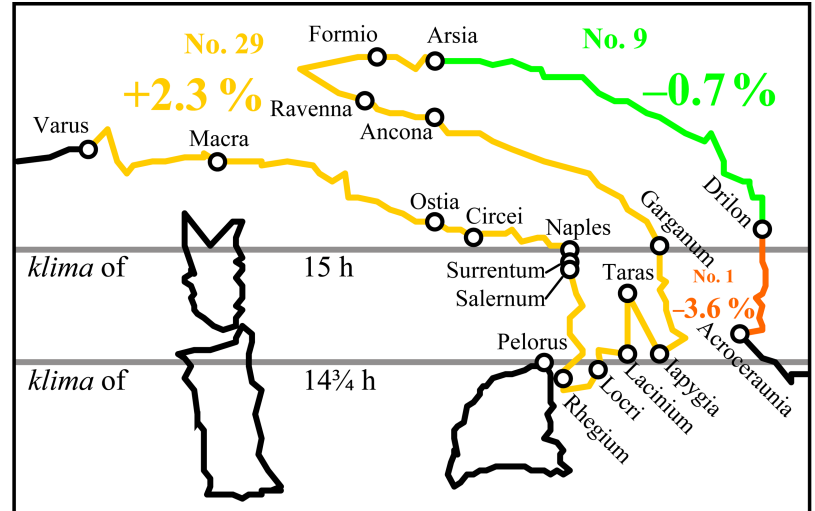

Figure 7. Pliny's points of the coast of Italy on Ptolemy's map ( $\Xi$ recension). The percentages refer to the deviation of Ptolemy's values for the coastline length from those given by Pliny (no. 29 in Table 1) and Agrippa (nos. 1 and 9).

\subsection{Italy}

Only a few ancient sources provide detailed information on individual distances along the coast. Pliny's description of Italy is among them (Natural History 3.49, 51, 56, 62, 70, 73, 95, 97, 99, 100, 111, 115, 127). Table 2 shows how Pliny's values for the separate coastal stretches constituting the perimeter of Italy relate to Ptolemy's data (see also Figs. 3 and 7).

Ptolemy's Italy may be divided into three parts (Fig. 7): (1) the northern part lying west of Ostia and Ancona, (2) the middle part lying east of Ostia and Ancona and north of Naples, and (3) the part lying to the south of Naples. Table 2 shows that for northern Italy Ptolemy's distances accord tolerably with Pliny's figures. ${ }^{17}$ Ptolemy's middle Italy

\footnotetext{
${ }^{17}$ Ptolemy's coast from Ravenna to the mouth of the Formio matches Pliny's distances pretty well. The length of the coast from the Varus to Cape Circei is exaggerated by $8 \%$ (or 42.5 m.p.) on
}

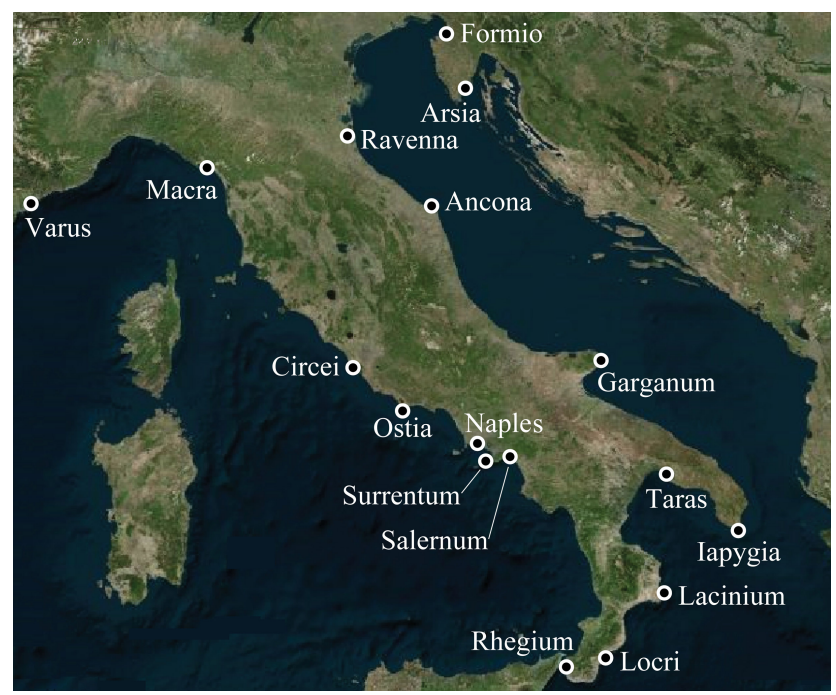

Figure 8. Pliny's points of the coast of Italy on the modern map.

is distinctly stretched in the east-west direction relative to Pliny's distances, whereas southern Italy is almost equally compressed. For example, Ptolemy's coast from Circei to Surrentum is stretched by 78 m.p., whereas that from Salernum to Rhegium is shortened by 83 m.p. Similar compressions and stretchings of these coastal sections are exhibited by Ptolemy's map relative to the modern map (Table 2, Fig. 8).

The compression of southern Italy in the north-south direction can be easily explained, first of all, by Ptolemy's underestimated value for the Earth's circumference. Ptolemy's latitudes for southern Italy are rather accurate: for example, the interval between his latitudes of Surrentum and Rhegium

average as compared to Pliny's figures, which is quite a lot, but it can still be explained by the fact that Ptolemy's data almost always exhibit a similar overestimation of distances relative to the periploi data (Table 1). 
Table 2. Comparison of the distances along the coast of Italy according to Pliny, Ptolemy, and measurements using Google Maps (Google Inc., 2017). All distances are expressed in terms of Roman miles; 1 m.p. $=1480 \mathrm{~m}$.

\begin{tabular}{|c|c|c|c|c|c|c|}
\hline \multirow[t]{2}{*}{$\begin{array}{l}\text { Stretches of the coast } \\
\text { from - to }\end{array}$} & \multirow[t]{2}{*}{$\begin{array}{r}\text { Pliny } \\
(\mathrm{P})\end{array}$} & \multicolumn{2}{|c|}{ Ptolemy } & \multicolumn{2}{|c|}{$\begin{array}{l}\text { Difference between } \\
\text { Pliny and } \Xi\end{array}$} & \multirow[t]{2}{*}{$\begin{array}{l}\text { Google } \\
\text { Maps* }\end{array}$} \\
\hline & & $\Xi$ & $\Omega$ & $\begin{array}{r}\text { m.p. } \\
(\Xi-P)\end{array}$ & $\begin{array}{r}\% \\
(\Xi-P) / P \times 100\end{array}$ & \\
\hline Varus-Macra & 211 & 219.1 & 214.8 & 8.1 & $3.8 \%$ & $154-182$ \\
\hline Macra-Tiber (Ostia) & 284 & 315.1 & 350.4 & 31.1 & $11 \%$ & $215-240$ \\
\hline Tiber (Ostia)-Cape Circei & 50 & 53.2 & 53.2 & 3.2 & $6.5 \%$ & $58-61$ \\
\hline Circei-Surrentum & 78 & 155.6 & 224.2 & 77.6 & $99.5 \%$ & 87 \\
\hline Surrentum-Salernum & 30 & 26.5 & 22.3 & -3.5 & $-11.5 \%$ & $36-37$ \\
\hline Salernum-Rhegium & 237 & 153.7 & 167.8 & -83.3 & $-35.1 \%$ & $200-236$ \\
\hline Rhegium-Locri & 66 & 73 & 71.7 & 7 & $10.7 \%$ & 100 \\
\hline Locri-Cape Lacinium & 86 or 75 & 67.4 & 71.7 & -18.6 or -7.6 & $-21.6 \%$ or $-10.1 \%$ & $83-95$ \\
\hline Tarentum (Taras)-Iapygia & 108 & 88 & 78.9 & -20 & $-18.5 \%$ & $90-100$ \\
\hline Iapygia-Garganum Mt & 234 & 177.3 & 189.9 & -56.7 & $-24.3 \%$ & $215-233$ \\
\hline Garganum-Ancona & 183 & 335.4 & 379.6 & 152.4 & $83.3 \%$ & $200-225$ \\
\hline Ancona-Ravenna & 105 & 88.3 & 88.6 & -16.7 & $-15.9 \%$ & 90 \\
\hline Ravenna-Formio & 189 & 183.9 & 187.9 & -5 & $-2.7 \%$ & $155-190$ \\
\hline
\end{tabular}

* The accuracy of this comparison should not be overestimated, because the routes on Google Maps have been measured rather arbitrarily. The lower and upper values in the table refer to the shortest route across the open sea and the route along the coast, respectively.

is $2^{\circ} 25^{\prime}$, which is pretty close to the true value of $2^{\circ} 30^{\prime}$. However, for Ptolemy the corresponding distance amounts to 150 m.p., whereas the correct value would have been 188 m.p.

Ptolemy's southern Italy is distinctly squeezed between the latitudes of Naples $\left(40^{\circ} 55^{\prime}\right.$ in $\Xi$; the true latitude is $40^{\circ} 50^{\prime}$ ) in the north and that of the Strait of Messina (in particular Cape Pelorus, $38^{\circ} 35^{\prime}$ in $\Omega$; the true latitude is $38^{\circ} 16^{\prime}$ ) in the south. These latitudes corresponded to the so-called klimata with the longest day of 15 and $143 / 4 \mathrm{~h}$, respectively. Klimata (sing. klima) was a technical term for latitudes defined by the length of the longest day. These klimata were, in essence, the principal tool available to pre-Ptolemaic geographers for constructing a mathematically rigorous map of the world, at least, from Eratosthenes onwards. ${ }^{18}$ A set of these klimata constituted the basis of the geographical system of Marinus of Tyre, Ptolemy's immediate predecessor and the principal source (Honigmann, 1930; Wurm, 1931). Therefore, Ptolemy's latitudes of Naples and Pelorus go back, most probably, to Marinus or even further.

It is striking that various divergences between Ptolemy's and Pliny's data on the separate coastal stretches (Table 2) ${ }^{19}$ are in stark contrast with the close agreement between their values for the total length of the coast: Ptolemy's figures for the perimeter of Italy and for the southern side from the

\footnotetext{
${ }^{18}$ On the system of klimata, see Honigmann (1929), Neugebauer (1975, p. 43-45, 333-336, 725-733), Shcheglov (2004); on klimata as a basis of Ptolemy's map, see Wurm (1931, p. 20-21, 30), Isaksen (2013, p. 50, Fig. 3.4).

${ }^{19}$ Similar observations have been made by Mittenhuber (2012) for Ptolemy's Hispania.
}

mouth of the Varus to Rhegium deviate from Pliny's values by only $2.4 \%$ (no. 29 in Table 1) and $3.7 \%$ (no. 19). Hence, it is tempting to explain this by assuming that the magnitude and direction of the disagreements may have been selected intentionally so that stretchings and compressions would have cancelled each other out.

\subsection{The Caspian Sea}

The coincidence between Ptolemy's and Artemidorus' values for the perimeter of the Caspian Sea gives us a key to explaining its strange configuration in Ptolemy's Geography, namely why it is shown as being longer from east to west (ca. 8250 stades from Gangara to the mouth of the Polytimetos) than from north to south (ca. 4400 stades between the mouths of the Rha and the Straton; see Fig. 3).

First of all, it is tempting to connect this anomaly with the fact that the whole of Ptolemy's map exhibits a similar stretching of all its outlines from east to west relative to the modern map. ${ }^{20}$ This stretching can largely be explained by Ptolemy's underestimated value for the Earth's circumference. This effect is due to the principal difference between the methods of measuring latitude and longitude (Shcheglov, 2016b; Graßhoff et al., 2016). Latitude can be determined by means of simple astronomical observations, which had been known to the Greeks since at least the 4th century BC, and starting at least with Hipparchus (2nd century BC) it was normally expressed in degrees. But it was not until the 18th century that an efficient and simple enough method

\footnotetext{
${ }^{20}$ On the variation in this error for different parts of Ptolemy's map, see Shcheglov (2016b).
} 
of determining longitude was devised. For an ancient geographer, the main method to find longitude was to convert distance measurements from customary linear units (Greek stades, Roman miles, etc.) to angular units (degrees), for which the estimate of the Earth's circumference was essential. This is why an error in this estimate inevitably affected all longitude values based on distance measurements, but had no effect on latitude values when they had been originally expressed in degrees. A too low value for the circumference of the Earth results in that all distances projected on its surface (i.e. converted to degrees) become proportionally overestimated in angular terms, which made the outlines on the map stretch mostly in the east-west direction (e.g. Russo, 2013; Shcheglov, 2016a, b). However, Ptolemy's underestimation of the size of the Earth could have been responsible for a stretching by only $17 \%$, which is evidently insufficient to explain the configuration of the Caspian Sea in his Geography.

Furthermore, Ptolemy's Caspian Sea is not only stretched from east to west but also compressed from north to south. The only ancient estimate of the north-south extension of the Caspian Sea comes from Strabo (2.1.17 C74): he defines the meridional distance between its southernmost end and the mouth entering the Ocean in the north as "about" ( $\pi \varepsilon \rho i$ ) 6000 stades. This value matches the actual straight-line length of the Caspian Sea pretty well (provided that 1 stade $=185 \mathrm{~m}$ ). However, Ptolemy's latitude interval between the northern (the mouth of the Rha at $48^{\circ} 50^{\prime}$ ) and the southern (the mouth of the Straton at $40^{\circ}$ ) extremities of the Caspian Sea corresponds to only 4417 stades (Fig. 3; of course, there is no reason to suppose that any of Ptolemy's latitudes for the Caspian Sea could have been based on actual astronomical observations).

The situation is complicated by the fact that there may have existed a hypothetical early version of Ptolemy's Geography that was based on a different estimate for the Earth's circumference, namely 252000 stades, which was ca. $16.5 \%$ above the true value $(252000 \times 185 \mathrm{~m}=46620 \mathrm{~km})$. This estimate was first proposed by Eratosthenes and can be regarded as almost generally accepted in antiquity. As has been shown by Schnabel (1930, p. 218-219), Ptolemy probably used this value for calculating geographic longitudes in the Almagest, one of his early works. Even more importantly, Sarre and Herzfeld (1911, p. 143-153), Wurm (1937, 1940), and Shcheglov $(2004,2017)$ have shown, independently of one another, that a large area on Ptolemy's map was built on the basis of Eratosthenes' set of distances which were converted to spherical coordinates according to Eratosthenes' rate of $1^{\circ}=700$ stades. This area covers the whole of the Middle East, at least, between the Euphrates and the Indus including the Caspian Sea. More importantly, Ptolemy's breadth of the Caspian Sea, when expressed in Eratosthenes' 700 -stade degrees, corresponds to 6183 stades which closely agrees with Strabo's distance, as was noted by Wurm (1937, p. 7, 13, 1940, p. 8, 11).
It is also remarkable that, on Ptolemy's map, the northern extremities of the Caspian Sea, as well as the northern coast of the Pontus Euxinus, are clearly tied to the latitude of the mouth of the Borysthenes $\left(481 / 2^{\circ}\right)$, one of the seven klimata or the key latitudes determining the structure of his map and going back, most probably, as far as Eratosthenes (Fig. 3). ${ }^{21}$ These correspondences make it possible to suppose that Ptolemy's meridional extension of the Caspian Sea had been originally defined as slightly more than 6000 stades and that this distance was expressed in degrees of latitude already in the early version of the map, which was based on Eratosthenes' value for the Earth's circumference.

Interestingly, 6183 stades is quite close to the quotient of 20000 stades (the perimeter of the Caspian Sea according to Artemidorus; no. 32 in Table 1) divided by $\pi$. If this coincidence is not accidental, and if the circumference of 20000 stades and the meridional extension of slightly more than 6000 stades were the two parameters that determined the outlines of the Caspian Sea from the very beginning, then it mathematically implies that in the early "Eratosthenic" version of Ptolemy's map the sea must have had a round shape. We may suppose that, when Ptolemy had accepted a smaller value for the Earth's circumference instead of Eratosthenes' 252000 stades, the meridional extension of the Caspian Sea, being expressed in degrees, remained unchanged, whereas its circumference was recalculated to the 500-stade degrees, which made the sea stretch from east to west and take the shape it has on Ptolemy's map today.

There is a difficulty, however, in that other ancient sources never compare the Caspian Sea with a circle. ${ }^{22}$ On the contrary, they often use quite different comparisons: a sickle or the horns of the crescent, or a mushroom cap. ${ }^{23}$ But this choice of metaphors might be due to the fact that, unlike Ptolemy, other sources considered the Caspian Sea as a gulf of the Ocean. Anyway, a circle seems to be the simplest and the most obvious figure that comes to mind to describe the shape of an unexplored sea or gulf about which almost nothing was known. ${ }^{24}$

\footnotetext{
${ }^{21}$ On Eratosthenes as a source of Ptolemy's seven klimata, see Honigmann (1929) and Shcheglov (2004).

${ }^{22}$ In contrast to, for example, the Persian Gulf which was described as "round" and "similar to a human head", see Agathem.

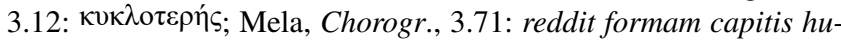
mani; Plin. 6.108: humani capitis effigie.

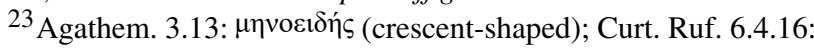
...lunae maxime similem, quum eminent cornua, quum eminent cornua, nondum totum orbem sidere implente; Plin. 6.38: .. . lunatis obliquatur cornibus ... sicilis, ut auctor est M. Varro, similitudine; Iordan. Getica 5.30: ab Oceano euroboro in modum fungi, primum tenui, posthaec latissima et rotunda forma exoritur; the same crescent-like shape of the Caspian Sea is seen on the so-called Tabula Peutingeriana, see http://www.cambridge.org/us/talbert/mapb/ TP2000seg11.jpg or http://peutinger.atlantides.org/map-a.

${ }^{24}$ Remarkably, there are two other seas that have regular rounded shapes in Ptolemy's Geography: the Bay of Ganges (modern Bay
} 
Table 3. Length of the Red Sea coast according to Artemidorus, Eratosthenes, Ptolemy, and measurements using Google Maps (Google Inc., 2017). All distances are expressed in stades; 1 stade $=185 \mathrm{~m}$.

\begin{tabular}{|c|c|c|c|c|c|c|c|c|}
\hline \multirow[t]{3}{*}{ Stretches of the coast } & \multicolumn{4}{|c|}{$\begin{array}{l}\text { Distance } \\
\text { (stades) }\end{array}$} & \multicolumn{2}{|c|}{$\begin{array}{l}\text { Difference between } \\
\Xi \text { and Artemidorus }\end{array}$} & \multicolumn{2}{|c|}{$\begin{array}{l}\text { Difference between } \\
\Xi \text { and Google Maps }\end{array}$} \\
\hline & \multirow{2}{*}{$\begin{array}{l}\text { Eratosthenes and } \\
\text { Artemidorus }(D)\end{array}$} & \multicolumn{2}{|c|}{ Ptolemy } & \multirow{2}{*}{$\begin{array}{r}\text { Google } \\
\text { Maps (GM) }\end{array}$} & \multirow{2}{*}{$\begin{array}{l}\text { stades } \\
(\Xi-D)\end{array}$} & \multirow[b]{2}{*}{$\begin{array}{l}(\Xi-D) / \\
D \times 100\end{array}$} & \multirow{2}{*}{$\begin{array}{r}\text { stades } \\
(\Xi-\mathrm{GM})\end{array}$} & \multirow[b]{2}{*}{$\begin{array}{r}(\Xi-\mathrm{GM}) / \\
\mathrm{GM} \times 100\end{array}$} \\
\hline & & $\Xi$ & $\Omega$ & & & & & \\
\hline Heroonpolis-Ptolemais & 9000 & 7575 & 7864 & $8108-8189$ & $-1,425$ & -15.8 & $-533-614$ & $-6.5-7.6$ \\
\hline Heroonpolis-Berenice & 4180 & 3266 & 3366 & 4324 & -914 & -21.9 & -1058 & -24.5 \\
\hline Berenice-Ptolemais & 4820 & 4310 & 4497 & $3784-3865$ & -510 & -10.6 & $445-526$ & $11.5-13.9$ \\
\hline Ptolemais-Deire & 6500 & 7944 & 8211 & $4700-4843$ & 1444 & 22.2 & 2766-2909 & $57.1-61.9$ \\
\hline
\end{tabular}

\subsection{The Red Sea}

The general configuration of the Red Sea (or, in ancient terms, the Arabian Gulf) on Ptolemy's map is determined by the latitudes of four points: Berenice, Ptolemais Theron, Adulis, and Ocelis (Fig. 3). ${ }^{25}$ The length of the African coast from Heroonpolis (the northernmost point) to Deire (situated opposite to Ocelis) in Ptolemy's work is exactly the same as in Artemidorus (in $\Xi$ it is only $0.1 \%$ or 19 stades shorter, in $\Omega$ it is $3.7 \%$ or 574 stades longer; see Table 1 ). However, the lengths of the separate coastal stretches recorded by Eratosthenes and Artemidorus relate to Ptolemy's data as follows.

Table 3 shows that the north-south stretch from Heroonpolis to Ptolemais is ca. 1425 stades shorter in Ptolemy than according to Artemidorus, while the next one turning to the east from Ptolemais to Deire is ca. 1444 stades longer. ${ }^{26}$ Similar deformations of these stretches are exhibited by Ptolemy's

of Bengal) and the Great Bay (the Tongking Gulf); see e.g. Stückelberger and Graßhoff (2006, p. 896-897, 902-903).

${ }^{25}$ In Ptolemy's Geography, Berenice is situated at the latitude of Syene $\left(23^{\circ} 50^{\prime}\right)$, Ptolemais at the latitude of Meroe $\left(16^{\circ} 30^{\prime}\right.$ in $\Xi$ and in Canon of the noteworthy cities 14.2 or $16^{\circ} 25^{\prime}$ in $\Omega$ ), which correspond to the klimata with the longest day of $131 / 2$ and $13 \mathrm{~h}$, respectively. Such arrangement of these points goes back as far as Eratosthenes (F IIB37-38, IIIA18 Berger = F 41-42, 59 Roller) or, at least, Hipparchus (F V4-V5 Berger $=$ F 46-47 Dicks $=$ Strab. 2.5.36 C133). Adulis (Almagest 2.6.4 Heiberg p. 105-106) and Ocelis (Geogr. 8.22.7) were presumably connected with the klima of the $123 / 4 \mathrm{~h}$ day $\left(12^{\circ} 30^{\prime}\right)$ in the early version of Ptolemy's map (see Wurm, 1931, 23-24), but in the final version they have been shifted to the latitudes of $11^{\circ} 40^{\prime}$ ( $\Xi$ and Canon of the noteworthy cities 14.2$)$ or $11^{\circ} 20^{\prime}(\Omega)$ and $12^{\circ}$, respectively. Modern latitudes of these points (according to the database of http://pleiades.stoa.org) are as follows: Berenice: $23^{\circ} 55^{\prime}$, Ptolemais: $18^{\circ} 13^{\prime}$, Adulis: $15^{\circ} 13^{\prime}$, Ocelis: $12^{\circ} 43^{\prime}$, Deire: $12^{\circ} 26^{\prime}$.

${ }^{26}$ Artemidorus gave 9000 stades for the distance from Heroonpolis to Ptolemais, and thence 6500 to Deire (Agathem. 3.14). However, according to Pliny (6.164), Artemidorus' values for the first distance was 9500. Eratosthenes gave also 9000 stades from Heroonpolis to Ptolemais, thence 4500 to Deire (F IIIB48 Berger $=$ F 95 Roller $=$ Strab. 16.4.4 C768), 4820 from Berenice to Ptolemais map relative to the modern map (Table 3). ${ }^{27}$ As in the case of Italy, the compression of the north-south coastal segment can be accounted for by Ptolemy's erroneous estimate of the circumference of the Earth, but the stretching of the segment Ptolemais-Deire by exactly the same amount seems suspicious and requires some additional explanation.

\section{Conclusions and further perspectives}

The main conclusion of our study is intuitively expectable and in this sense unsurprising, namely that Ptolemy's Geography was most likely based on some ancient periploi similar to those known from other sources. What seems unexpected and much more important is that our study has revealed a close numerical agreement between Ptolemy's $G e$ ography and the other periploi-based sources in the data on the length of relatively long coastlines (over 10000 stades): in most cases the differences between Ptolemy's data and the other sources fall between +4 and $-1 \%$. This observation can provide a new insight into the genesis of Ptolemy's Geography and the history of ancient geography in general.

A major challenge we face now is how to reconcile this striking agreement between Ptolemy's data and the other sources with the equally striking contradictions between them in the short coastal stretches of which the long ones consist (as was demonstrated by the example of Italy). In other words, with increase in the coastline lengths being compared, different discrepancies between Ptolemy and the other sources compensate one another until an almost complete agreement is reached. But what factors determined this transformation? Could it be intentional, or just accidental, and to what extent? This question compels us to revisit our understanding of Ptolemy's methods and the relevancy of our methods of examining his work. For the time being, we

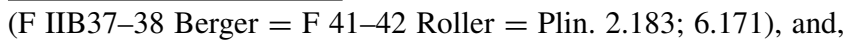
accordingly, 4180 from Heroonpolis to Berenice.

${ }^{27}$ However, a part of this deformation is due to the fact that Ptolemy and his predecessors placed Ptolemais $2^{\circ}$ too far to the north of Marsa Aqiq, its modern counterpart. 
may only suggest a preliminary explanation. Most plausibly, Ptolemy's map was constructed not "bottom-up" - when its outlines would have been drawn successively point by point like beads are strung on a thread, but "top-down" - when the cartographer first drew the general outlines determined by long distances, and only after that he inserted minor details, fitted into the general picture. This assumption can be corroborated in part by the three cases (Italy, the Caspian Sea, and the Red Sea) where Ptolemy's Geography exhibits a proportional shortening of the north-south sections of coastline and stretching of the neighbouring east-west sections relative to the distances recorded in other sources. Whereas the shortening of the north-south sections was definitely caused by Ptolemy's underestimate of the circumference of the Earth, the stretching of the east-west sections is hard to explain, unless by assuming that the cartographer deliberately compensated the shortening. Of course, three cases are not enough for definitive conclusions, and the issue awaits further investigation.

Data availability. Ptolemy's coordinates are taken from the electronic database attached to the newest edition of the Geography (Stückelberger and Graßhoff, 2006). 


\section{Appendix A: Pliny's "third gulf" of Europe}

In addition to the materials presented in Table 1 , one case needs to be considered separately. Pliny (4.1), without indicating his source, estimates the perimeter of the so-called "third gulf" of Europe from the Acroceraunia Promontory (modern Karaburun) to the Hellespont (Dardanelles) at 1925 m.p. $=15400$ stades "without minor gulfs" (praeter minores sinus). Since it is not known which gulfs he regarded as "minor", it is hazardous to rely on this evidence. Nevertheless, we can try, as an experiment, to measure the coast from the Acroceraunia to Sestos (as the major point on the Hellespont) in Ptolemy's Geography without the most prominent of the "minor gulfs" mentioned by Pliny (Fig. A1). ${ }^{28}$ Without these gulfs, the coastline length measures 15778 stades in $\Xi$ or 15714 stades in $\Omega$, which is quite close to Pliny's figure. When measured including all the gulfs, it would amount to 21552 stades in $\Xi$ or 21589 in $\Omega$.

\footnotetext{
${ }^{28}$ The Ambracian Gulf (between Nicopolis and Leucas), the Corinthian (between capes Antirrhion and Drepanon), the Messenian (between capes Akritas and Tainaros), the Laconian (between capes Tainaros and Malea), the Argolic (between capes Malea and Skyllaion), the Thermaic, Toronic, and Singitic gulfs (of course, this choice is rather arbitrary).
}

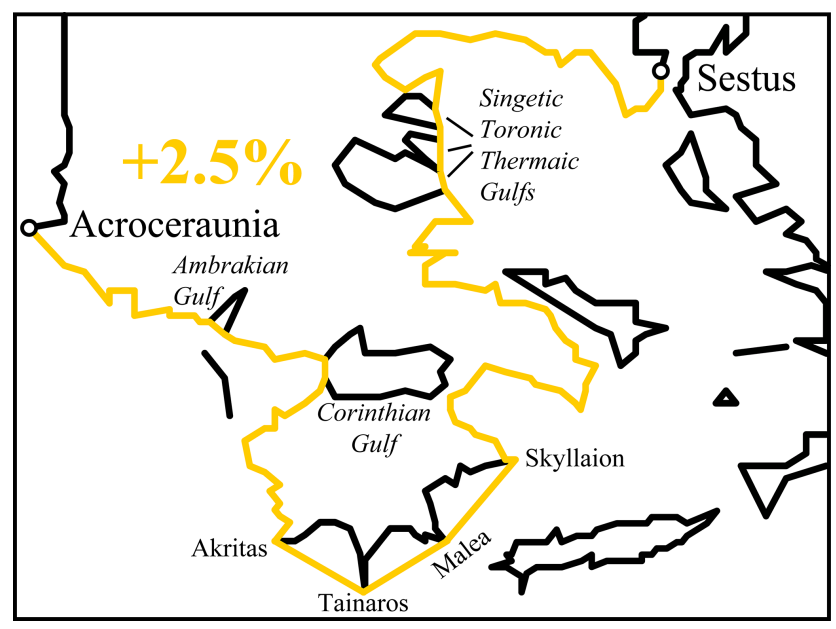

Figure A1. The outlines of Pliny's "third gulf" of Europe on Ptolemy's map ( $\Xi$ recension) without the "minor gulfs" (shown with yellow). 


\section{The Supplement related to this article is available online at https://doi.org/10.5194/hgss-9-9-2018-supplement.}

Competing interests. The author declares that he has no conflict of interest.

Acknowledgements. I would like to thank Pascal Arnaud, Georgia Irby, Roel Nicolai, Eugene Rodin, and two anonymous referees whose comments greatly improved parts of the article. This work would be impossible without help from Alexandra Elbakyan and her project Sci-Hub.

This article is a part of the research project "Internal Structures of Ptolemy's Map" supported by the Russian Foundation for Basic Research (grant 15-01-00005).

Edited by: Giovanni P. Gregori

Reviewed by: Roel Nicolai, Pascal Arnaud, Georgia Irby, and two anonymous referees

\section{References}

Arnaud, P.: De la durée à la distance: l'évaluation des distances maritimes dans le monde gréco-romain, Histoire \& Mesure, 8.3, 225-247, 1993.

Arnaud, P.: Le traitement cartographique de l'information périplographique et diaplographique par Ptolémée: quelques exemples, Geographia Antiqua, 26, 3-21, 2017.

Berger, H.: Die geographischen Fragmente des Eratosthenes, B. G. Teubner, Leipzig, 1880.

Berggren, J. L. and Jones, A.: Ptolemy's Geography: an Annotated Translation of the Theoretical Chapters, Princeton University Press, Princeton, 2000.

Burri, R.: Die Geographie des Ptolemaios im Spiegel der griechischen Handschriften, De Gruyter, Berlin/Boston, 2013.

Cuntz, O.: Die Geographie des Ptolemaeus, Galliae Germania Raetia Noricum Pannoniae Illyricum Italia. Handschriften, Text und Untersuchung, M. G. Weidmann, Berlin, 1923.

Defaux, O.: The Iberian Peninsula in Ptolemy's Geography. Origins of the Coordinates and Textual History, Edition Topoi, Berlin, 2017.

Detlefsen, D.: Varro, Agrippa und Augustus als Quellenschriftsteller des Plinius für die Geographie Spaniens, in: Commentationes philologiae in honorem Th. Mommsen, M. G. Weidmann, Berlin, 23-34, 1877.

Detlefsen, D.: Vermuthungen über Varros Schrift De ora maritima, Hermes, 21, 240-265, 1886.

Diller, A.: The Tradition of the Minor Greek Geographers, Lancaster Press/B. H. Blackwell, Lancaster/Oxford, 1952.

Diller, A.: Agathemerus, Sketch of Geography, Greek Roman Byzantin., 16, 59-76, 1975.

Gómez Fraile, J. M.: Sobre la antigua cartografía y sus métodos. Los fundamentos numéricos de la Hispania de Claudio Ptolomeo, Iberia, 8, 35-64, 2005.

Google Inc.: Google Maps, available at: https://www.google.com/ maps, last access: 22 November 2017.
Graßhoff, G., Rinner, E., Ossendrijver, M., Defaux, O. Schreiber, M., and Villey, E.: Longitude, in: Special Volume 6: Space and Knowledge, edited by: Graßhoff, G. and Meyer, M., eTopoi, 634-677, 2016.

Graßhoff, G., Rinner, E., and Mittenhuber, F.: Of paths and places: the origin of Ptolemy's Geography, Arch. Hist. Exact Sci., 71, 483-508, https://doi.org/10.1007/s00407-017-0194-7, 2017.

$\mathrm{He} \beta$, J.: Neue Hinweise auf die Kartenkonstruktion in der Geographie des Klaudios Ptolemaios, available at: https://www.juergenhess.org/themen/ koordinatenermittlung-bei-ptolemaios-2016-1/ (last access: 20 September 2017), 2016.

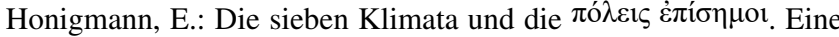
Untersuchung zur Geschichte der Geographie und Astrologie im Altertum und Mittelalter, C. Winter's Universitätsbuchhandlung, Heidelberg, 1929.

Honigmann, E.: Marinos 2, in: Real-Encyclopädie der classischen Altertumswissenschaft, 14.2, J. B. Metzler, Stuttgart, 17671794, 1930.

Isaksen, L.: Lines, damned lines and statistics: unearthing structure in Ptolemy's Geographia, e-Perimetron, 6.4, 254-260, 2011.

Isaksen, L.: "O what a tangled web we weave" - towards a practice that does not deceive, in: Network Analysis in Archaeology: New Approaches to Regional Interaction, edited by: Knappett C., Oxford University Press, Oxford, 43-67, 2013.

Jan, L. and Mayhoff, C. (Eds.): C. Plinii Secundi Naturalis Historiae libri XXXVII, vol. 1, B. G. Teubner, Leipzig, 1892.

Janni, P.: La mappa e il periplo: cartografia antica e spazio odologico, G. Breitschneider, Roma, 1984.

Klotz, A.: Die geographischen commentarii des Agrippa und ihre Überreste, Klio, 24, 38-58, 386-466, 1931.

Knapp, R. C.: Ptolemy mapping Baetica, The Classical Bulletin, 72.1, 29-36, 1996.

Marx, C.: On the precision of Ptolemy's geographic coordinates in his Geographike Hyphegesis, Hist. of Geo-Space Sci., 2, 29-37, 2011.

Marx, C.: The western coast of Africa in Ptolemy's Geography and the location of his prime meridian, Hist. Geo Space. Sci., 7, 27 52, https://doi.org/10.5194/hgss-7-27-2016, 2016.

Meuret, C.: Outils mathématiques et données itinéraires: réflexions sur l'évaluation de la circonférence terrestre chez Ptolémée, Geographica Historica: L'utilisation des géographes anciens par l'historien de l'Antiquité, edited by: Arnaud P. and Counillon P., Ausonius-Etudes, Bordeaux/Nice, 151-165, 1998.

Mittenhuber, F.: Gemeinsamkeiten und Unterschiede in den geographischen Werken des Artemidor und des Klaudios Ptolemaios, in: Intorno al Papiro di Artemidoro II: Geografia e Cartografia, Atti del Convegno internazionale del 27 novembre 2009 presso la Società Geografica Italiana. Villa Celimontana, Roma, Colloquium, edited by: Gallazzi, C., Kramer, B., and Settis, S., LED Edizioni, Milano, 157-174, 2012.

Müller, C. (Ed.): Geographi graeci minores, A. F. Didot, Paris, 1855.

Neugebauer, O.: A History of Ancient Mathematical Astronomy, Pt. 1-3, Springer, Berlin/Heidelberg/New York, 1975.

Polaschek, E.: Klaudios Ptolemaios. Das geographische Werk, in: Real-Encyclopädie der classischen Altertumswissenschaft, suppl. X, A. Druckenmüller, Stuttgart, 680-833, 1965. 
Purcell, N.: Periploi, in: Oxford Classical Dictionary, edited by: Hornblower, S., Spawforth, A., and Eidinow, E., 4th Edn., Oxford University Press, Oxford/New York, 1107-1108, 2012.

Radt, S. (Ed.): Strabons Geographika: mit Übersetzung und Kommentar, Vandenhoeck \& Ruprecht, Göttingen, 1-10, 2003-2011. Riese, A.: Geographi latini minors, Heinniger, Heilbronn, 1878.

Roller, D. W.: Eratosthenes' Geography, Fragments Collected and Translated, with Commentary and Additional Material, Princeton University Press, Princeton/Oxford, 2010.

Russo, L.: Ptolemy's longitudes and Eratosthenes' measurement of the Earth's circumference, Math. Mech. Complex Syst., 1.1, 6779, 2013.

Sarre, F. and Herzfeld, E. E.: Archäologische Reise im Euphrat- und Tigris-Gebiet, vol. 1, D. Reimer, Berlin, 1911.

Schiano, C.: Artemidoro di Efeso e la scienza del suo tempo, Edizioni Dedalo, Bari, 2010.

Schnabel, P.: Die Entstehungsgeschichte des kartographischen Erdbildes des Klaudios Ptolemaios, Sitzungs-Berichte der Preussischen Akademie der Wissenschaften, Philosophisch-historische Klasse, 14, 214-250, 1930.

Schnabel, P.: Text und Karten des Ptolemäus, K. F. Koehlers, Leipzig, 1938.

Seabra Lopes, L.: Itinerários da estrada Olisipo-Brácara: contributo para o estudo da Hispania de Ptolomeu, O Arqueologo Português, Série IV, 13/15, 313-346, 1995-1997.

Shcheglov, D. A.: Ptolemy's system of seven climata and Eratosthenes' geography, Geographia Antiqua, 13, 21-37, 2004.

Shcheglov, D. A.: The error in longitude in Ptolemy's Geography revisited, Cartogr. J., 53.1, 3-14, 2016a.

Shcheglov, D. A.: The accuracy of ancient cartography reassessed: the longitude error in Ptolemy's map, Isis, 107.4, 687-706, $2016 b$.

Shcheglov, D. A.: Eratosthenes' contribution to Ptolemy's map of the world, Imago Mundi, 69.2, 159-175, 2017.
Spaul, J. E. H.: Studies in the Roman province of Mauretania Tingitana, Part 1: The Geography of Tingitana, $\mathrm{PhD}$ dissertation, Durham University, available at http://etheses.dur.ac.uk/10374 (last access: 30 June 2017), 1958.

Stückelberger, A. and Graßhoff, G. (Eds.): Klaudios Ptolemaios: Handbuch der Geographie, Griechisch-Deutsch, Einleitung, Text und Übersetzung, vols. 1-2, CD-Rom, Schwabe, Basel, 2006.

Stückelberger, A. and Mittenhuber, F. (Eds.): Klaudios Ptolemaios: Handbuch der Geographie. Ergänzungsband mit einer Edition des Kanons bedeutender Städte, Schwabe, Basel, 2009.

Uggeri, G.: Stadiasmus Maris Magni: un contributo per la datazione, in: L'Africa Romana: atti dell'XI convegno di studio Cartagine (15-18 dicembre 1994), edited by: Khanoussi, M., Ruggeri, P., and Vistnara, C., Editrice Il torchietto, Cartagine, Sassari, 277-285, 1996.

Urueña Alonso, J.: El item ab Hispali Cordvbam en la Geographia de Ptolomeo. Una propuesta de interpretación del método cartográfico Ptolemaico, Habis, 45, 137-150, 2014a.

Urueña Alonso, J.: El método cartográfico de Ptolomeo: análisis del sistema de localización utilizado en la Geographia para la ubicación de las poblaciones del interior de la península Ibérica, Palaeohispanica, 14, 153-185, 2014b.

Wurm, A.: Marinus of Tyre (Some Aspects of His Work), B. Stýblo, Chotěboř, available at: https://drive.google.com/open? id=0ByHnqj0cHCZMU3pQOWJtcDgzVFk (last access: 30 June 2017), 1931.

Wurm, A.: Mathematické základy mapy Ptolemaiovy, B. Stýblo, Chotěboř, available at: https://drive.google.com/open?id= 0ByHnqj0cHCZMdmNpdkE2NEJxQTQ (last access: 30 June 2017), 1937.

Wurm, A.: O vzniku a vývoji mapy Ptolemaiovy, B. Stýblo, Chotěboř, available at: https://drive.google.com/open?id= 0ByHnqj0cHCZMZVdOQ3hDMWJRbnM (last access: 30 June 2017), 1940. 